\title{
Telomerase regulation by the long non-coding RNA H19 in human acute promyelocytic leukemia cells
}

Joëlle El Hajj ${ }^{1,2,3,4}$, Eric Nguyen ${ }^{1,2}$, Qingyuan Liư ${ }^{1,2,6}$, Claire Bouyer ${ }^{1,2}$, Eric Adriaenssens ${ }^{5}$, George Hilal ${ }^{4}$ and Evelyne Ségal-Bendirdjian ${ }^{1,2,3,7^{*}}$ (D)

\begin{abstract}
Background: Since tumor growth requires reactivation of telomerase (hTERT), this enzyme is a challenging target for drug development. Therefore, it is of great interest to identify telomerase expression and activity regulators. Retinoids are well-known inducers of granulocytic maturation associated with hTERT repression in acute promyelocytic leukemia (APL) blasts. In a maturation-resistant APL cell line, we have previously identified a new pathway of retinoid-induced hTERT transcriptional repression independent of differentiation. Furthermore, we reported the isolation of a cell variant resistant to this repression. Those cell lines could serve as unique tools to identify new telomerase regulators.
\end{abstract}

Methods: Using a microarray approach we identified the long non-coding RNA, H19 as a potential candidate playing a role in telomerase regulation. Expression of H19, $h T E R T$, and $h T R$ were examined by quantitative reverse transcriptase polymerase chain reaction (qRT-PCR). Telomerase activity was quantified by quantitative telomeric repeats amplification protocol (qTRAP). In vitro and in vivo assays were performed to investigate H19 function on telomerase expression and activity.

Results: We showed both in retinoid-treated cell lines and in APL patient cells an inverse relationship between the expression of H19 and the expression and activity of hTERT. Exploring the mechanistic link between H19 and hTERT regulation, we showed that H19 is able to impede telomerase function by disruption of the hTERT-hTR interaction.

Conclusions: This study identifies a new way of telomerase regulation through H19's involvement and thereby reveals a new function for this long non-coding RNA that can be targeted for therapeutic purpose.

Keywords: Telomerase, hTERT, hTR, H19 long non-coding RNA, Retinoids, Acute promyelocytic leukemia

\section{Background}

Human telomerase is a special ribonucleoprotein enzyme that stabilizes chromosome ends by adding (TTAGGG) $)_{\mathrm{n}}$ telomeric sequences and thus has a key role in maintaining telomere length and in cellular replicative life-span. This ribonucleoprotein, usually absent or expressed at a low level in most normal somatic cells, is highly active in cancer cells, and plays a key role in cell immortalization and tumorigenesis $[1,2]$. Due to this differential expression pattern, telomerase has been

\footnotetext{
* Correspondence: evelyne.segal-bendirdjian@inserm.fr

'INSERM UMR-S 1007, Cellular Homeostasis and Cancer, Paris, France

${ }^{2}$ Paris-Descartes University, Paris Sorbonne Cité, Paris, France

Full list of author information is available at the end of the article
}

proposed as a promising target for anticancer therapies. Therefore, different therapeutic approaches for telomerasebased treatment of cancer have been developed [3, 4]. The main levels on which telomerase activity can be targeted are associated with transcription of $h T E R T$ and $h T R$ genes, as well as disruption of the telomerase complex assembly, inhibition of the assembled telomerase complex and its interaction with telomeres [4].

Retinoids are well-known inducers of granulocytic maturation of primary acute promyelocytic leukemia (APL) blasts. Previous studies, including our own on the NB4 cellular model of APL, showed that $h T E R T$ repression is associated with cell differentiation. In a maturation-

(c) The Author(s). 2018 Open Access This article is distributed under the terms of the Creative Commons Attribution 4.0 International License (http://creativecommons.org/licenses/by/4.0/), which permits unrestricted use, distribution, and 
resistant APL cell line (NB4-LR1), we showed that retinoids can regulate telomerase and telomere length independently of cell maturation leading to growth arrest and cell death [5, 6]. Moreover, we reported the isolation of a variant of the NB4-LR1 cell line, named NB4-LR1 ${ }^{\text {SFD }}$, which is resistant to ATRA-induced cell death. In NB4LR1 ${ }^{\text {SFD }}$ cells, hTERT has been stably reactivated despite the continuous presence of ATRA [7]. This stable telomerase reactivation after an initial step of downregulation seems similar to what occurs during tumorigenesis when telomerase becomes reactivated. Therefore, the NB4-LR1 ${ }^{\mathrm{SFD}}$ cell line is a valuable cell model to study the molecular events occurring during the oncogenic reactivation of telomerase.

Using a microarray approach to identify genes differentially modulated by ATRA treatment in NB4-LR1 and NB4-LR $1^{\text {SFD }}$ cells, we found an inverse correlation between the expression of hTERT and the long noncoding RNA, H19. We set out to explore this potential correlation and the underlying mechanistic link between H19 expression and hTERT regulation and showed that H19 is able to impede telomerase function by disrupting the hTERT- $h T R$ interaction. This finding identifies for the first time a new way of telomerase regulation by retinoids through $H 19$ 's involvement and thereby reveals a new function of this long non-coding RNA.

\section{Methods}

\section{Chemicals, cell lines, and cell cultures}

All-trans retinoic acid (ATRA), 8-(4-chlorophenylthio) adenosine $3^{\prime}, 5^{\prime}$-cyclic adenosine monophosphate (8-CPTcAMP), and protease inhibitor cocktail (P8340) were purchased from Sigma (St Louis, MO, USA). The maturation sensitive NB4 cells and both maturation-resistant human APL cell lines, NB4-LR1 and NB4-LR1 ${ }^{\mathrm{SFD}}$, were cultured as previously described [5]. The NB4-LR1 ${ }^{\mathrm{SFD}}$ cell line was isolated as a population of cells emerging from a culture of NB4-LR1 cells under the selective presence of ATRA $(1 \mu \mathrm{M})$. It bypasses the death step induced by long-term ATRA treatment because of the reactivation of hTERT. The established NB4-LR1 ${ }^{\text {SFD }}$ cell line is stable and able to grow either in the presence or in the absence of ATRA. This property of resistance to ATRA-induced cell death during a prolonged treatment is maintained for more than 6 months of culture in the absence of ATRA. Therefore both NB4LR1 and NB4-LR1 ${ }^{\text {SFD }}$ cells were routinely cultured in the same ATRA-free RPMI medium.

All cells were cultured at $37{ }^{\circ} \mathrm{C}$ in a humidified incubator with $5 \% \mathrm{CO}_{2}$ (Binder Incubators, Nanterre, France). Cell density was determined every 2 or 3 days using Coulter counting, and when it reached $6-7 \times 10^{5}$ cells $/ \mathrm{ml}$, cells were re-seeded in a new flask containing fresh medium.

\section{RNA extraction and processing for microarray} experiments

NB4-LR1 and NB4-LR1 ${ }^{\text {SFD }}$ cells were treated or not for 7 days with ATRA $(1 \mu \mathrm{M})$. Total cellular RNA from 3 independent experiments (biological replicates) was extracted using TRIzol reagent (Invitrogen) according to the manufacturer's instructions. After validation of the RNA quality with Bioanalyzer 2100 (using Agilent RNA6000 nano chip kit), 500 ng of total RNA was reverse transcribed following the GeneChip ${ }^{\circ}$ WT Plus Reagent Kit (Affymetrix) instructions. Briefly, the resulting double strand cDNA is used for in vitro transcription with T7 RNA polymerase (all these steps are included in the WT cDNA synthesis and amplification kit of Affymetrix). After purification according to Affymetrix protocol, $5.5 \mu \mathrm{g}$ of the cDNA obtained are fragmented and biotin-labeled using Terminal Transferase (using the WT terminal labeling kit of Affymetrix). cDNA is then hybridized to GeneChip $^{\text {tw }}$ Human Transcriptome Array 2.0 (HTA 2.0.) (Affymetrix) at $45^{\circ} \mathrm{C}$ for $17 \mathrm{~h}$.

After overnight hybridization, chips were washed on the fluidic station FS450 following specific protocols (Affymetrix) and scanned using the GCS3000 7G. The scanned images were then analyzed with Expression Console software (Affymetrix) to obtain raw data (CEL files) and metrics for Quality Controls. The observations of some of these metrics and the study of the distribution of raw data show no outlier experiments. CEL files were then normalized and processed to signal intensities using the RMA (robust multi-array average) algorithm from the Bioconductor library and the cdf file V20 from BrainArray. All subsequent analyses were done on the log (base 2) transformed data in Partek Genomics Suite: non supervised analysis and analysis of variance (ANOVA) were used to detect eventual outlier samples and to identify differentially expressed genes. A global view of the differentially expressed genes was drawn using a Volcano Plot, the log transformed adjusted $p$-values plotted on the $y$-axis and $\log 2$ fold change values on the $x$-axis. A cut-off value of $p<0.01$ was chosen for statistical significance. The expression of the significant genes was displayed in a heatmap. The statistically significant differential gene expression list was further trimmed by considering only genes with $\mid$ fold change $\mid>2$ as biologically significant. Venn diagrams were generated using Venny tool (http://bioinfogp.cnb.csic.es/tools/venny/index.html).

\section{Quantitative reverse transcriptase polymerase chain reaction (qRT-PCR)}

Total RNA was isolated from cells as mentioned above. RNA concentration and quality were determined via A260/230 and A260/A280 nm absorbance with Nanodrop Spectrophotometer. One microgram of total RNA was subjected to reverse transcriptase (RT) reaction 
using Transcriptor First Strand cDNA Synthesis kit (Roche Diagnostics) according to the manufacturer's instructions with random hexamer primers. The cDNAs were subsequently analyzed by quantitative real-time PCR using the LightCycler technology and the Light Cycler FastStart DNA MasterPLUS SYBR Green Kit (Roche Diagnostics) according to the manufacturer's instructions. hTERT, $h T R$ and H19 levels were normalized to the expression of glyceraldehyde-3-phosphate dehydrogenase $(G A P D H)$ serving as the internal control gene. Primer sequences are shown in Additional file 1: Table S1. All samples were analyzed in triplicate in at least three independent experiments.

\section{Quantitative RT- PCR for detection of miR-675-5p and miR-675-3p}

Total RNA was extracted as previously described. The expression of miR-675-5p and miR-675-3p was quantified by quantitative RT-PCR. Single strand RNA is first polyadenylated by poly(A)polymerase before reverse transcription into cDNA using qScript RT with a proprietary adapter oligo $(\mathrm{dT})$ primer. Using the kit: "the qScript microRNA cDNA Synthesis Kit" (Quanta Biosciences, VWR), following the manufacturer's protocol. The step of amplification was carried out using the LightCycler technology, the PerfecCTa microRNA Assay, the PerfeCTa Universal PCR Primer and miRNA specific primers (Quanta Biosciences). SNORD44 serves as an internal control. The miRNA specific primers are listed in Additional file 1: Table S1.

\section{Production of RNA molecules for in vitro studies}

Plasmids pcDNA 3.1(+)-H19 and pcDNA 3.1(+)-GFP (green fluorescent protein, used in control experiments) were linearized with the restriction enzyme BamH1 $(20 \mathrm{U} / \mu \mathrm{l})$. The products of digestion were purified using the plasmid DNA purification kit (Nucleobond ${ }^{\circ}$ PC20, Macherey Nagel) and used as templates for subsequent in vitro transcription. H19 and GFP RNA molecules were generated by in vitro transcription using the T7 RNA polymerase (Roche). The reaction was performed in a final volume of $20 \mu \mathrm{l}$ containing $1 \mu \mathrm{g}$ of linearized plasmid, $1 \times$ reaction buffer ( $40 \mathrm{mM}$ Tris, $\mathrm{pH} 8.0,6 \mathrm{mM}$ $\mathrm{MgCl}_{2}, 2 \mathrm{mM}$ spermidine, $10 \mathrm{mM}$ DTT, $10 \mathrm{mM}$ each ATP, GTP, UTP, and CTP, $1 \mu \mathrm{l}$ RNase inhibitor $(20 \mathrm{U} / \mu \mathrm{l})$ , and $2 \mu \mathrm{l}$ T7 RNA polymerase $(20 \mathrm{U} / \mu \mathrm{l})$. The reaction mix was incubated at $37{ }^{\circ} \mathrm{C}$ for $2 \mathrm{~h}$ before treatment with RNase-free DNase I ( $1 \mathrm{U} / \mu \mathrm{l}$, Promega) at $37^{\circ} \mathrm{C}$ for $30 \mathrm{~min}$ and the reaction was terminated by adding $2 \mu \mathrm{l}$ $0.2 \mathrm{M}$ EDTA and heating at $65{ }^{\circ} \mathrm{C}$ for $10 \mathrm{~min}$. In vitro transcribed products were separated from unincorporated nucleotides with the RNeasy Mini kit (Qiagen) and stored at $-80^{\circ}$ until used.

\section{Measurement of telomerase activity}

Samples for telomerase activity assays were extracted following standard protocols. Briefly, cell pellets were resuspended $\left(10^{6}\right.$ cells in $\left.200 \mu \mathrm{l}\right)$ in lysis buffer (3-[(3cholamidopropyl)-dimethylammonio]-1-propane-sulfonate, $10 \mathrm{mM}$ Tris $\mathrm{pH}$ 8.0) and incubated on ice for $30 \mathrm{~min}$. After centrifugation at $16000 \mathrm{~g}$ for $20 \mathrm{~min}$. at $4{ }^{\circ} \mathrm{C}$, aliquots of the supernatant were rapidly frozen and stored at $-80{ }^{\circ} \mathrm{C}$. The protein concentration of extracts was determined with the BCA Protein Assay (Thermo Scientific).

Real-time quantitative telomeric repeat amplification protocol (qTRAP) assay was performed as described [8]. Briefly, reactions were carried out in 20- $\mu$ l with LightCycler $^{\circ}$ FastStart DNA Master SYBR Green I (Roche) with $0.1 \mu \mathrm{g}$ of telomerase primer TS, $0.05 \mu \mathrm{g}$ of reverse primer ACX, and $2 \mu \mathrm{l}$ of the sample to be tested. Samples were incubated $30 \mathrm{~min}$. at $37{ }^{\circ} \mathrm{C}, 10 \mathrm{~min}$. at $95^{\circ} \mathrm{C}$ and amplified for $40 \mathrm{PCR}$ cycles $\left(5 \mathrm{~s}\right.$ at $95{ }^{\circ} \mathrm{C}$ and $60 \mathrm{~s}$ at $\left.60{ }^{\circ} \mathrm{C}\right)$. Data analysis was performed with the LightCycler software that integrates the real-time PCR efficiency that was calculated by serial dilution of the most active sample. Primer sequences are shown in Additional file 1: Table S1.

In vitro qTRAP was designed to test whether H19 RNA fragments would inhibit telomerase enzymatic activity in vitro. Cell extracts ( $1 \mu \mathrm{g}$ of protein) were mixed with the indicated amount of in vitro transcribed $H 19$ or GFP RNA and telomerase activity was quantified using the qTRAP assay as described above.

\section{Nucleofection of DNA constructs}

Transfections were performed using the Amaxa Nucleofector technology. NB4 cells were transfected using $2 \mu \mathrm{g}$ of either pcDNA $3.1(+)$-H19 or pcDNA $3.1(+)$-empty vector, using transfection solution $\mathrm{V}$ and program 001 , according to the manufacturer's instructions. Six hours after transfection, RNA and proteins were extracted as previously described. H19 and $h T E R T$ levels were quantified by qRT-PCR, telomerase activity was measured using qTRAP assay as described above.

\section{Immunoprecipitation (IP) of hTERT-hTR complexes}

To prepare the antibody-coated beads, $30 \mu \mathrm{l}$ of protein A/G magnetic beads (Thermo Scientific) were incubated with $4 \mu \mathrm{g}$ of polyclonal anti-hTERT antibodies or $4 \mu \mathrm{g}$ of rabbit pre-immune IgG in $150 \mu \mathrm{l}$ IP buffer (1\% Igepal CA630, $137 \mathrm{mM} \mathrm{NaCl}, 20 \mathrm{mM}$ Tris- $\mathrm{HCl}$ at $\mathrm{pH} 8.0,10 \%$ glycerol, and $2 \mathrm{mM}$ EDTA) at $4{ }^{\circ} \mathrm{C}$ for at least $2 \mathrm{~h}$. Then, the beads were washed three times with IP buffer and kept on ice until used. To prepare cell lysates, cells were harvested by centrifugation at $220 \mathrm{~g}$ and cell pellets resuspended in $300 \mu \mathrm{l}$ of freshly prepared lysis buffer $(0.5 \%$ $\mathrm{Na}$ deoxycholate, 1\% IGEPAL CA-630, 0.1\% SDS, $150 \mathrm{mM} \mathrm{NaCl}, 50 \mathrm{mM}$ Tris- $\mathrm{HCl}$ at $\mathrm{pH}$ 7.8, $10 \mathrm{mM}$ EDTA, $1 \times$ protease inhibitor cocktail, $1 \mathrm{mM}$ PMSF, $5 \mathrm{mM} \mathrm{NaF}$, 
$1 \mathrm{mM}$ sodium orthovanadate, and $4 \mathrm{U} / \mu \mathrm{l}$ RNase inhibitor). The suspensions were incubated on ice for $20 \mathrm{~min}$. After removing insoluble materials by centrifugation, lysates were transferred to tubes containing hTERT antibody (Rockland) or pre-immune IgG-coated beads, and IP was carried out by rotating the tubes at $4{ }^{\circ} \mathrm{C}$ overnight. Beads were then washed briefly three times and RNAs were eluted by incubating the beads in $100 \mu \mathrm{l}$ buffer $(20 \mathrm{mMTris}-\mathrm{HCl}$ $\mathrm{pH}$ 8.0, $137 \mathrm{mM} \mathrm{NaCl}, 10 \%$ glycerol, $1 \% \mathrm{NP}-40,2 \mathrm{mM}$ EDTA) containing $0.8 \%$ SDS and $1.2 \mathrm{~g} / \mathrm{l}$ Proteinase K, during $30 \mathrm{~min}$. at $55{ }^{\circ} \mathrm{C}$ with shaking. Eluted beads were discarded using a magnet and the supernatant processed with TRIzol reagent. The resulting RNA preparations were analyzed for the presence of $h T R$ by quantitative RT-PCR as described above.

In some experiments, $10 \mu \mathrm{g}$ of in vitro transcribed H19 RNA molecules were preincubated with $100 \mu \mathrm{g}$ of cellular extracts for $30 \mathrm{~min}$. at room temperature. This mixture was added to tubes containing hTERT antibody, and IP was carried out by rotating the tubes at room temperature for $90 \mathrm{~min}$. The samples were then processed as above for $h T R$ quantification. As a control, an in vitro transcribed GFP RNA was used.

\section{Statistical analysis}

Statistical analysis was conducted using GraphPad Prism 6.01 software. The difference between groups was analyzed using unpaired or paired Student's t-test when there were only two groups or assessed by one-way ANOVA followed by the Tukey's multiple comparison tests when there were more than two groups. All tests carried out were two-tailed. Differences were considered as significant when $p<0.05$.

\section{Results}

The induction of $\mathrm{H} 19$ expression by ATRA treatment of the maturation resistant NB4-LR1 and NB4-LR1 ${ }^{\mathrm{SFD}}$ cells is associated with hTERT repression

A transcriptomic analysis on microarray was performed on the two ATRA-induced maturation-resistant NB4-LR1 and NB4-LR1 ${ }^{\text {SFD }}$ cell lines to identify genes differentially expressed upon ATRA treatment. We isolated total RNAs from ATRA-treated or non-treated cells NB4-LR1 and NB4-LR1 ${ }^{\text {SFD }}$ cells. Day 7 was chosen because, at this time of treatment, the $h T E R T$ expression level was reduced in NB4-LR1 cells (to about 90\% of the non-treated cells), whereas it was stabilized in NB4-LR1 ${ }^{\mathrm{SFD}}$ cells (at about $60 \%$ of the non-treated cells) (Fig. 1a).

Transcriptome profiling identified in NB4-LR1 cells, 256 genes that were differentially expressed between ATRAtreated and non-treated cells. Among these, 183 were upregulated and 73 were downregulated. In NB4-LR1 ${ }^{\text {SFD }}$ cells, only 65 genes were differentially expressed between treated and non-treated cells. Among them, 25 were downregulated whereas 40 were upregulated (Additional file 2: Table S2). The differentially expressed genes were visualized in the form of a volcano plot (Fig. 1b). The expression of the significant genes was displayed in a heatmap (Fig. 1c). Venn diagram representation (Fig. 1d) showing the overlap between genes up- or down-regulated in NB4-LR1 treated vs control cells and NB4-LR1 ${ }^{\text {SFD }}$ treated vs control cells enabled us to focus our attention on $\mathrm{H} 19$ gene, coding a long non-coding RNA, because it is the only gene whose expression was induced after ATRA treatment in NB4-LR1 cells but repressed in NB4-LR1 ${ }^{\mathrm{SFD}}$ cells exposed to the same treatment.

To validate this observation, qRT-PCR was performed to investigate $H 19$ expressions in NB4-LR1 and NB4-LR1 ${ }^{\text {SFD }}$ cells treated with ATRA $(1 \mu \mathrm{M})$ for different times. Figure 2a showed that the constitutive H19 expression is higher in NB4-LR1 ${ }^{\text {SFD }}$ than in NB4-LR1 cells. The expression of $h T R$ and $h T E R T$ RNA were also higher in NB4LR1 ${ }^{\mathrm{SFD}}$ compared to NB4-LR1 cells, which is consistent with a difference in telomerase activity. In NB4-LR1 cells, ATRA treatment induced a strong increase in the expression of $H 19$ associated with a progressive decrease of hTERT expression. In contrast, in the NB4-LR $1^{\mathrm{SFD}}$ cell line, as already reported in Fig. 1a, despite the continuous presence of ATRA, a high level of hTERT mRNA (more than $50 \%$ of expression compared to the untreated cells) of control expression) and telomerase activity was maintained. This partial resistance to ATRA-induced hTERT repression was associated with an important decrease of H19 expression after a slight but significant increase (Fig. 2b). Note that $h T R$ expression level was not modified upon ATRA treatment in both cell lines.

We have previously shown that $h T E R T$ repression by prolonged ATRA treatment was reversible [5]. Similarly, in both NB4-LR1 and NB4-LR1 ${ }^{\mathrm{SFD}}$ cells, the effects of ATRA treatments on $H 19$ expression were reversible (Fig. 3a). Indeed, the withdrawal of ATRA from cell cultures at day 8 induced a complete (NB4-LR1) or partial return (NB4-LR1 ${ }^{\mathrm{SFD}}$ ) of $H 19$ expression to the baseline level before ATRA treatment. In parallel, hTERT expression is nearly (NB4-LR1) or completely restored (NB4-LR1 ${ }^{\mathrm{SFD}}$ ) in cells after ATRA removal. It is worthy to mention, as previously noticed, that $h T R$ expression level remained unchanged as compared with the control cells throughout the experiment.

The NB4-LR1 ${ }^{\mathrm{SFD}}$ cell line was generated after a prolonged culture of NB4-LR1 cells under the selective presence of ATRA [7]. This cell line that has been established as a permanent cell line, overcomes the death induced through a telomere-dependent pathway, proliferates, and expresses high levels of telomerase despite continuous ATRA treatment (Figs. 1a and 2b). We performed a new similar experiment on NB4-LR1 cells in order to investigate H19 expression during 


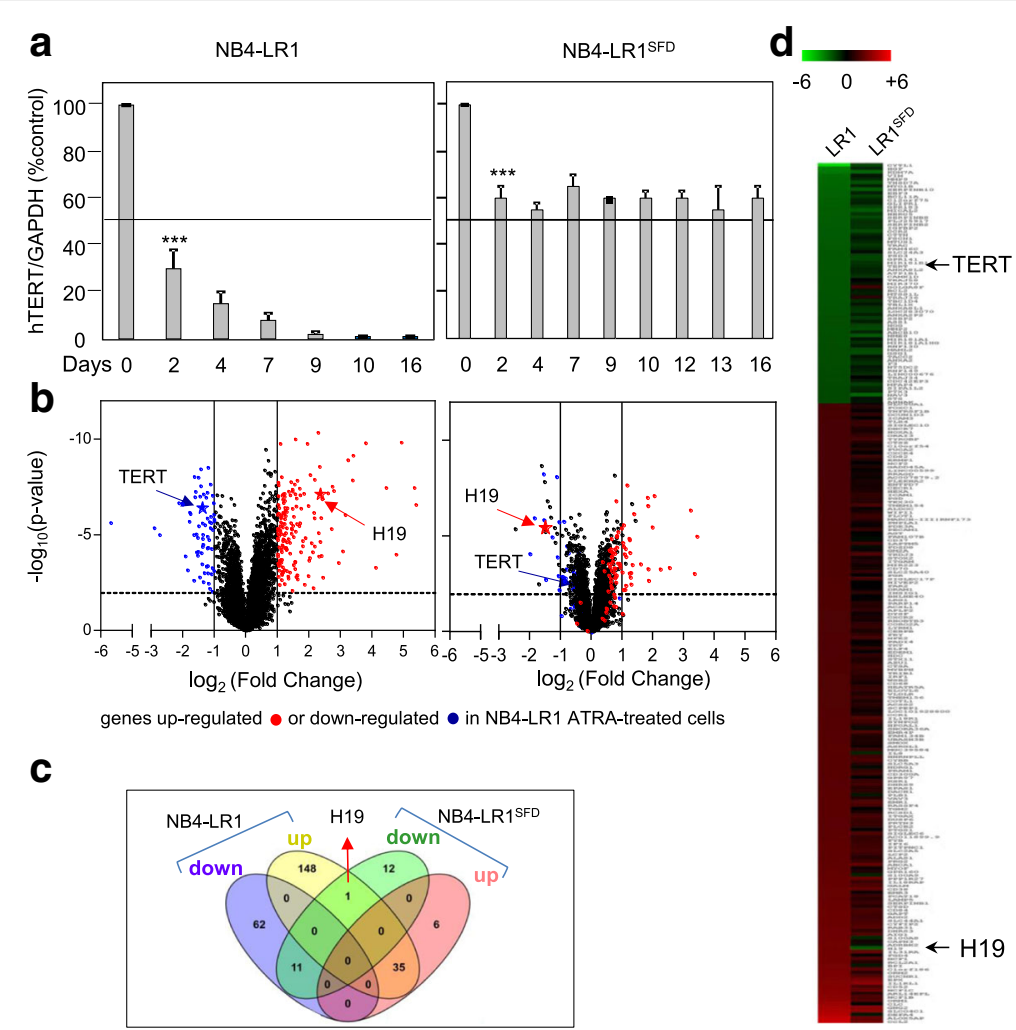

Fig. 1 Microarray-based expression profiling. a Kinetics of hTERT expression in NB4-LR1 and NB4-LR1 ${ }^{\text {SFD }}$ cells treated with ATRA (1 $\mu M$ ). b Volcano plot representation of the differentially expressed genes in a pair wise comparison of NB4-LR1 (left panel) and NB4-LR1 ${ }^{\text {SFD }}$ (right panel) cells treated with ATRA $(1 \mu \mathrm{M})$ for 7 days. The plot indicates - $\log _{10}\left(p\right.$-value) for genome-wide genes $\left(Y\right.$-axis) plotted against their respective $\log _{2}$ (fold change) (X-axis). The significant cut-off was set to a $p$-value of 0.01 ( $\log _{10}$ ( $p$-value) $\geq-2$, horizontal line), the biological cut-off was set to a fold change of \pm 2 fold ( $\log _{2}$ (fold change) $<-1$ and $>+1$, vertical lines). In ATRA-treated vs non-treated NB4-LR1 cells (left panel) biological and statistically insignificant genes are presented in black. A color was attributed to each gene whether it is significantly up-regulated (red) or down-regulated (blue). A star indicates hTERT and H19 genes in blue and red, respectively. Importantly, in the NB4-LR1 ${ }^{\text {SFD }}$ right panel, all genes retained the color defined in the NB4-LR1 left panel. Therefore H19, in red in the NB4-LR1 Volcano panel, remained in red in the NB4-LR1 ${ }^{\text {SFD }}$ Volcano panel, even though its expression was repressed. c Heat map of expression profiles of genes that were differentially expressed in NB4-LR1 compared to NB4-LR1 ${ }^{\text {SFD }}$ ATRA-treated cells. Red indicates upregulated genes and green indicates downregulated genes $\mathbf{d}$ Venn diagrams showing the number of significantly differentially expressed genes (up-regulated and down-regulated) at 7 days of ATRA treatment (1 $\mu$ M) in NB4-LR1 and NB4-LR1 ${ }^{\text {SFD }}$. Figures in the overlapping sections indicate the number of differentially expressed genes common to multiple pair-wise cell lines comparison. H19 is the only gene to be up-regulated in NB4-LR1 ATRA-treated cells but down-regulated in the NB4-LR1 ${ }^{\text {SFD }}$ cells after ATRA treatment. Lists of corresponding genes are presented in Additional file 2 (Table S2)

the procedure of selection of resistant cells to ATRAinduced $h T E R T$ repression. As previously observed [7], many attempts failed and cells died upon ATRA prolonged exposure. However, in two separate experiments, a population of cells emerged from the culture by day 50. Examination of hTERT and H19 expressions revealed that the high repression of hTERT during the first 5 weeks of treatment was associated with a high increase of H19 expression (Fig. 3b). However, around day 50, when most of the cells progressed toward the death we observed a rapid decrease of $H 19$ expression and the re-expression of $h T E R T$ associated with recovered cell growth despite the continuous presence of ATRA.
H19 encodes two conserved miRNAs processed from its first exon, miR-676-5p and miR-675-3p [9]. Using several in silico bioinformatics web-based analysis including TargetScan (URL:http://www.targetscan.org), RNA22 (URL: https://cm.jefferson.edu/rna22), and miRanda (URL:https://omictools.com/miranda-tool), we found that hTERT mRNA was predicted as a potential, target of miR-675-5p, although poorly conserved. Therefore, we investigated the expression of this miRNA in both cell lines before and after ATRA treatment (Additional file 3: Figure S1a and b). The expression of miR-675-5p did not exhibit any significant difference either before or after ATRA treatment of NB4-LR1 and NB4-LR1 ${ }^{\mathrm{SFD}}$. Of note only a 

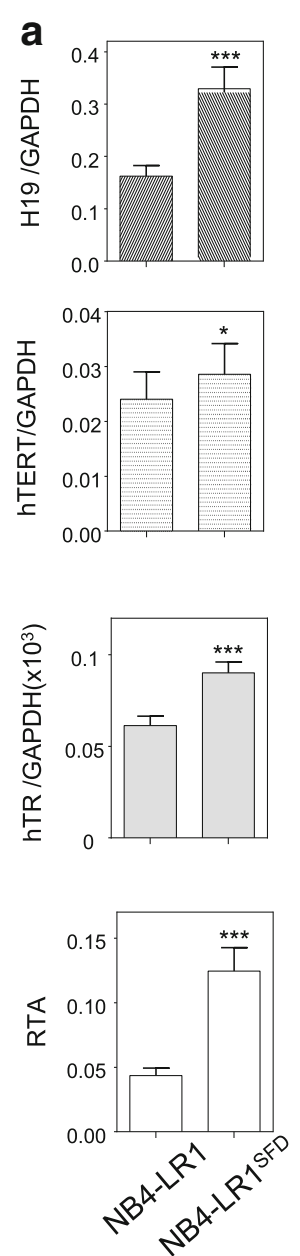

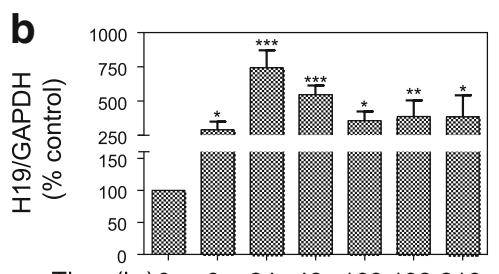

Time (hr)0 $6 \begin{array}{llllll}6 & 24 & 48 & 168 & 192216\end{array}$
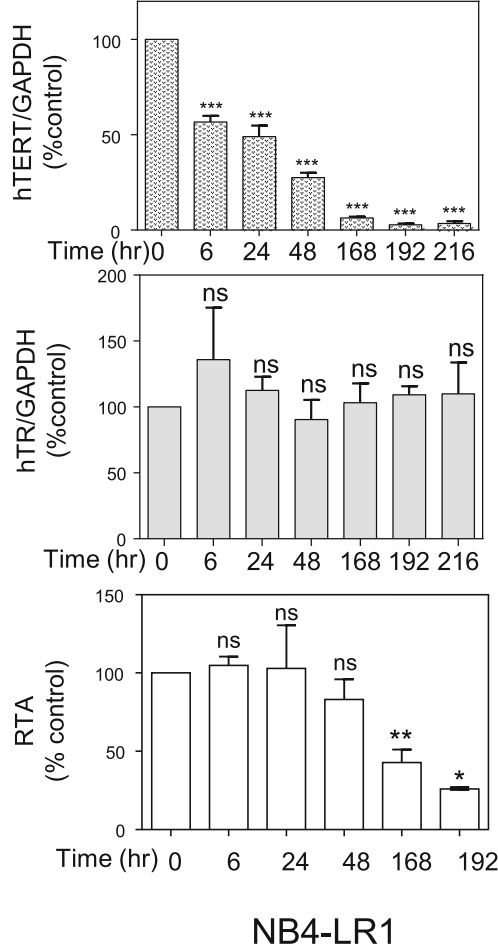

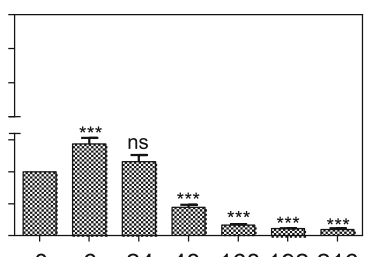

$\begin{array}{lllllll}0 & 6 & 24 & 48 & 168 & 192 & 216\end{array}$

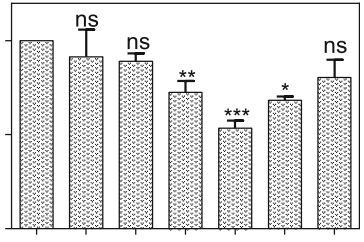

$\begin{array}{lllllll}0 & 6 & 24 & 48 & 168 & 192 & 216\end{array}$
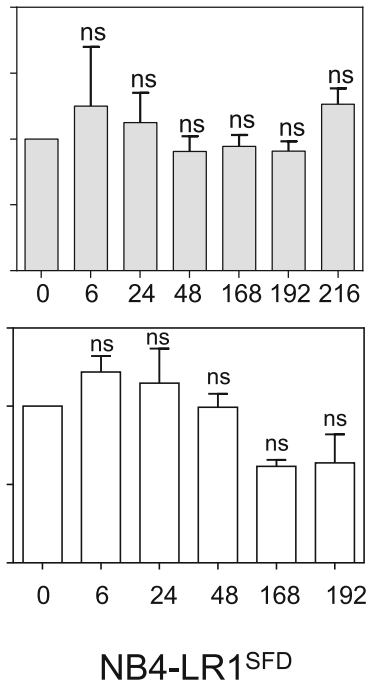

Fig. $2 \mathrm{H} 19$ is induced upon ATRA treatment in NB4-LR1 cells in association with hTERT repression, whereas it is repressed in the NB4-LR1 ${ }^{\mathrm{SFD}}$ cells resistant to ATRA-induced $h T E R T$ repression. a Basal expression levels of H19, $h T R$, and $h T E R T$ MRNA and relative telomere activity (RTA) in NB4-LR1 and NB4-LR1 ${ }^{\text {SFD }}$ cells. $\mathbf{b}$ Expression levels of H19, hTR, and hTERT mRNA and RTA after treatment of NB4-LR1 and NB4-LR1 ${ }^{\text {SFD }}$ cells with ATRA $(1 \mu \mathrm{M})$ for the indicated time. All experiments were repeated at least 3 times. Expression levels were normalized to GAPDH expression. RTA measured by qTRAP as described in "Methods" is expressed as the percentage of that detected in the untreated cells. Results were expressed as means $+/$ - SEM. t-test (a) or one way ANOVA with post-hoc Tukey, ns $p>0.05,{ }^{*} p<0.05,{ }^{* *} p<0.001,{ }^{* * *} p<0.001$

significant increase of miR-675-3p expression was observed in ATRA-treated NB4-LR1 cells.

\section{H19 expression is induced in the NB4-LR1 ${ }^{\mathrm{SFD}}$ cells by alternative treatments that repress $h T E R T$ expression and decrease telomerase activity}

In contrast with the parental NB4 cells that are sensitive to ATRA-induced maturation, both NB4-LR1 and NB4LR1 ${ }^{\text {SFD }}$ cell variants fail to mature upon ATRA treatment alone. However, maturation can be rapidly induced following the cooperative stimulation by ATRA and cAMP analog [7, 10]. This maturation has been associated with $h T E R T$ repression and a decrease of telomerase activity. Therefore, the expression of $H 19$ was measured in NB4-LR ${ }^{\mathrm{SFD}}$ cells during the induction of maturation by the combination of ATRA and the
cAMP analog, 8-CPT-cAMP. As shown in Fig. 4a, this combination induced in the NB4-LR1 ${ }^{\mathrm{SFD}}$ cells an increase of H19 expression associated with a maturationdependent repression of $h T E R T$. Of note, 8-CPT-cAMP treatment alone induced a strong increase of $H 19$ expression. This increase was accompanied with a reduction of hTERT mRNA level similar to that seen after ATRA treatment (about 30\%). However, 8-CPT-cAMP treatment of these cells induced also a reduction of telomerase activity not observed after ATRA treatment. This suggests that the decrease of telomerase activity cannot be explained by $h T E R T$ repression alone. Considering that arsenic trioxide $\left(\mathrm{As}_{2} \mathrm{O}_{3}\right)$ combined with ATRA is also able to repress $h T E R T$ in the NB4-LR1 ${ }^{\mathrm{SFD}}$ cells [11], we conducted an experiment to determine whether this combination affects also $H 19$ expression. As previously shown, we observed 

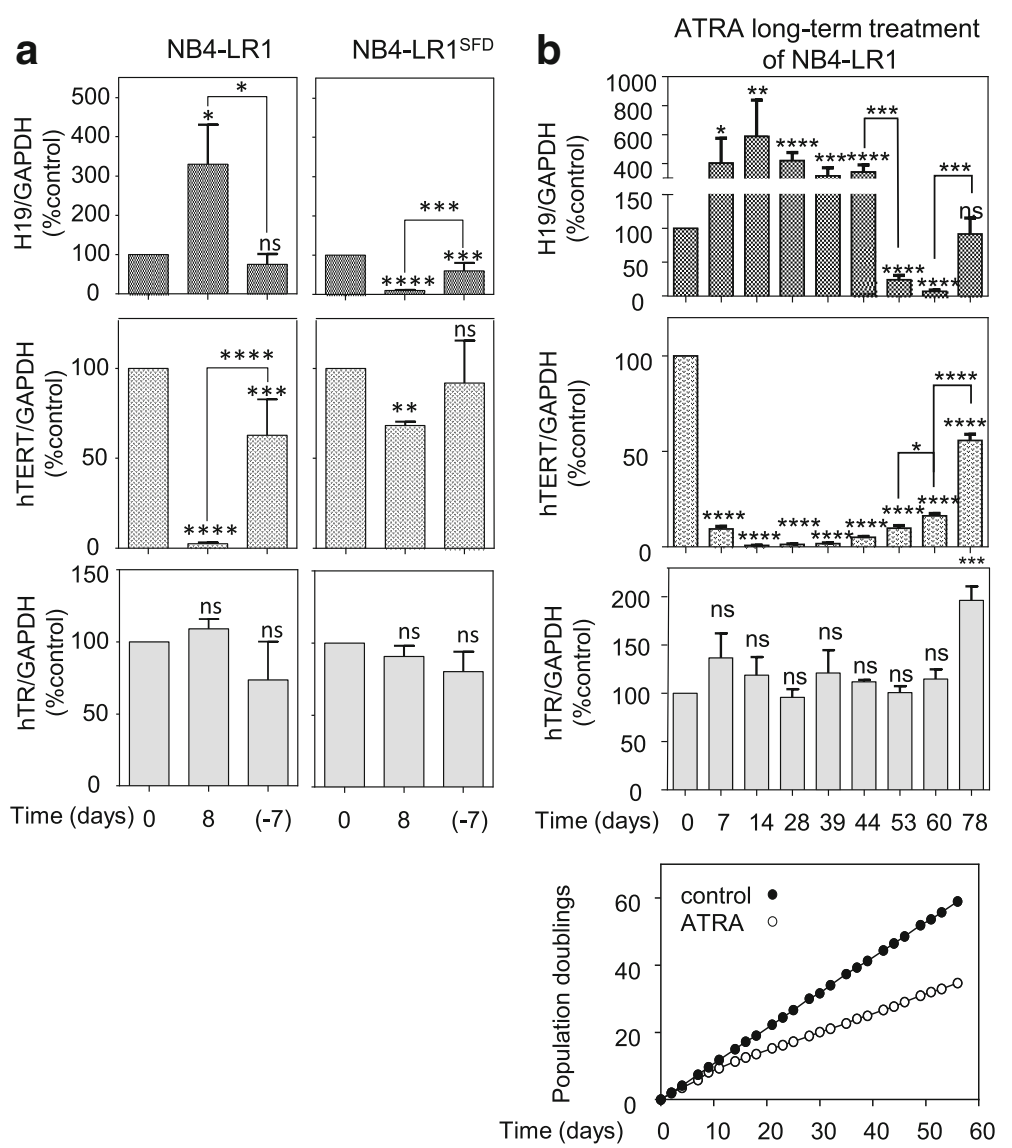

Fig. 3 a The effects of ATRA treatment on $\mathrm{H} 19$ expression are reversible in both NB4-LR1 and NB4-LR1 ${ }^{\text {SFD }}$. After culturing cells for 8 days in the presence of ATRA $(1 \mu \mathrm{M})$, the NB4-LR1 cell culture was switched to ATRA-free medium. ( -7$)$ refers to the NB4-LR1 cells that were cultured 7 days after ATRA removal. Expression levels of H19, hTERT mRNA, and hTR were quantified and normalized to GAPDH expression. Results were expressed as means +/- SEM. One way ANOVA with post-hoc Tukey, ns $p>0.05,{ }^{*} p<0.05$, ${ }^{* *} p<0.001,{ }^{* * * *} p<0.0001$. b Establishment of an NB4-LR1 ${ }^{\text {SFD }}$ like cell line from NB4-LR1 cell line cultured in the continuous presence of ATRA (1 $\mu \mathrm{M})$. By day 50, in several experiments, most of the cells underwent cell death. However, in two separate experiments a new population, similar to the NB4-LR1 ${ }^{\text {SFD }}$, overcame this cell death step. The lower panel shows the population doublings of one of the two cultures. At the indicated times, RNA was extracted and hTERT, H19, and hTR expressions measured. Expression levels were normalized to GAPDH expression. Note from day 53 the decrease of H19 expression (upper panel) associated with $h$ TERT re-expression (middle panel) t-test or one way ANOVA with post-hoc Tukey, ns $p>0.05,{ }^{*} p<0.05,{ }^{* * *} p<0.001 .{ }^{* * *} p<0.0001$

that, in NB4-LR1 $1^{\mathrm{SFD}}$ cells, this combined treatment induced a repression of $h T E R T$ (Fig. 4b). Moreover, this repression was associated with an increased $H 19$ expression. The treatment with $\mathrm{As}_{2} \mathrm{O}_{3}$ alone changed neither expressions of $H 19, h T E R T$ and $h T R$ nor activity of telomerase. Altogether, these observations demonstrate that, in the NB4-LR1 ${ }^{\text {SFD }}$ cells, different treatments that increase $H 19$ expression lead to a decrease of telomerase activity associated to a certain extent with hTERT gene repression.

\section{An inverse correlation between the expressions of hTERT and $H 19$ is observed in APL patients}

Given the above results demonstrating, in the APL cellular model, an inverse correlation between H19 and hTERT expression levels, we wondered whether this correlation could be found also in APL patient cells.
Therefore, we analyzed the expression levels of hTERT and $H 19$ using publicly accessible expression profiles of 16 APL patients (TCGA, http://cbioportal.org). As indicated in Fig. 5, there was a negative correlation between $H 19$ and $h T E R T$ expressions in these patients $(r=-0.500$, $p<0.05)$. This observation reinforces the idea that there is a link between H19 and hTERT.

\section{H19 LncRNA inhibits telomerase activity}

To examine an effect of H19 on hTERT expression or telomerase activity independently of ATRA treatment, we performed a transient overexpression of H19. This experiment was performed on the parental NB4 cells since in these cells transfection is much more efficient and much less toxic than in NB4-LR1 and NB4-LR1 ${ }^{\text {SFD }}$ cell sublines. The results in Fig. 6a indicate that H19 overexpression in NB4 cells led to a significant decrease 

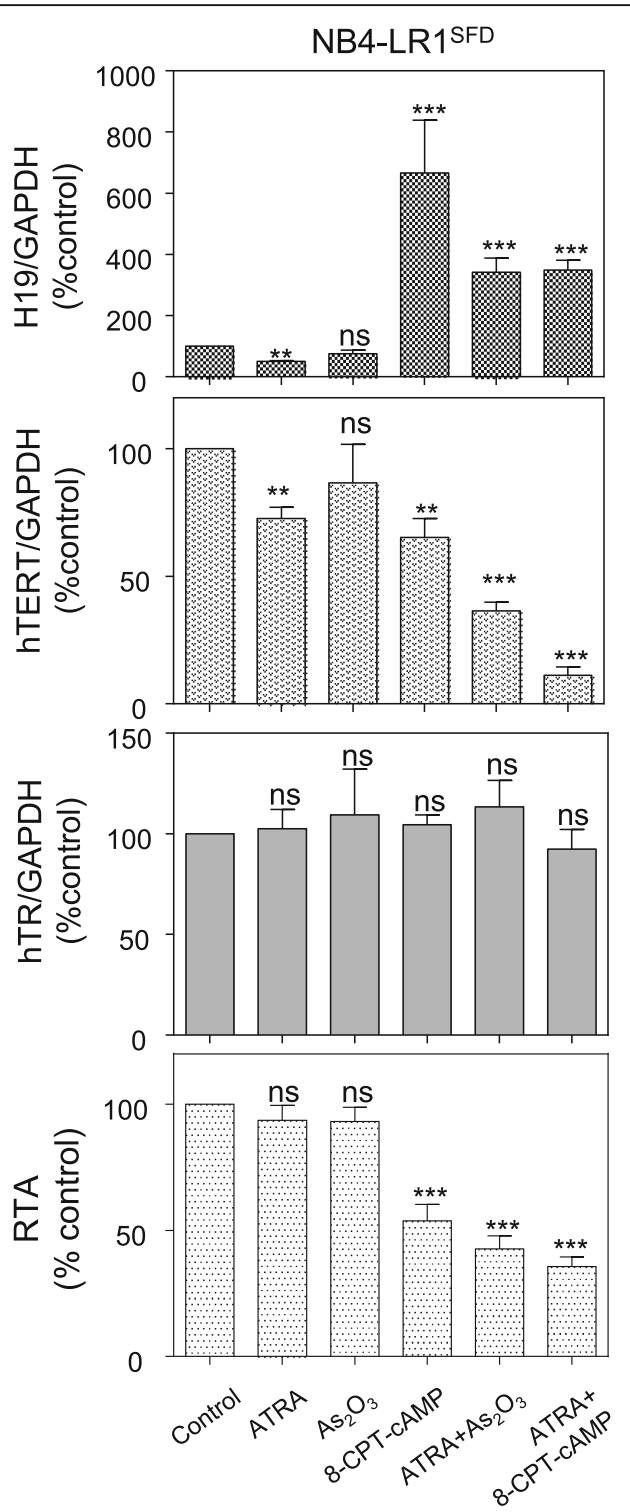

Fig. $4 \mathrm{H} 19$ expression is induced in the NB4-LR1 ${ }^{\mathrm{SFD}}$ cells by alternative treatments. Expression levels of H19, hTERT, and hTR and telomerase activity after treatment of NB4-LR1 ${ }^{\mathrm{SFD}}$ cells for $48 \mathrm{~h}$ with ATRA $(1 \mu \mathrm{M})$ alone or in combination with either 8-CPT-CAMP $(100 \mu \mathrm{M})$ or Arsenic trioxide $\left(\mathrm{As}_{2} \mathrm{O}_{3}, 0.2 \mu \mathrm{M}\right)$.. Expression levels were normalized to GAPDH expression. Results were expressed as means $+/$ - SEM. t-test or one way ANOVA with post-hoc Tukey, ${ }^{*} p<0.05$, ${ }^{* *} p<0.01,{ }^{* * *} p<0.001,{ }^{* * * *} p<0.0001$

of telomerase activity measured by TRAP assay compared to NB4 cells transfected with empty pcDNA $3.1(+)$ vector, whereas no significant change in neither $h T E R T$ mRNA nor in $h T R$ levels was observed.

To explore further the interfering effect of $\mathrm{H} 19$ on telomerase activity, we performed a qTRAP assay in cell extracts from NB4-LR1 cells incubated with increasing amounts of in vitro transcribed H19 RNA. Figure 6b

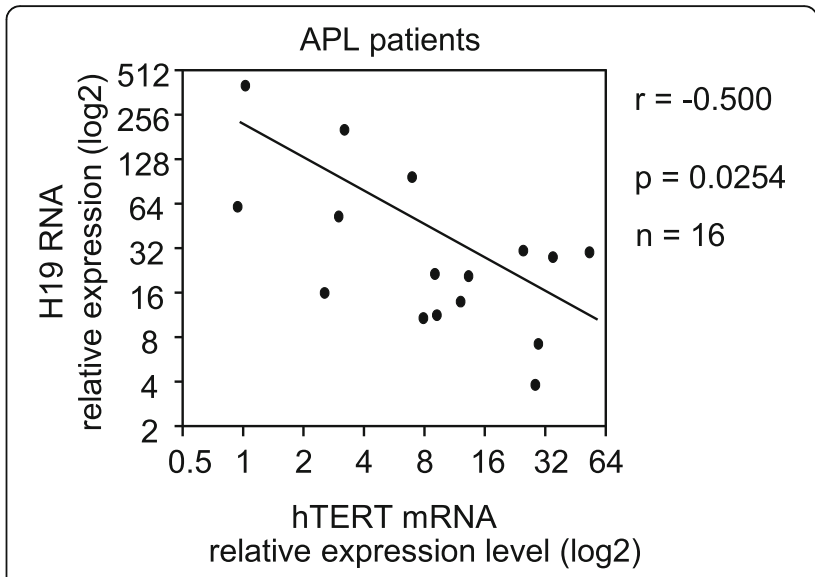

Fig. 5 Negative correlation between the expression of hTERT and H19 in acute promyelocytic leukemia patients. The correlation analysis of $\mathrm{H} 19$ and hTERT expression was performed using the Pearson correlation test with the software of GraphPad Prism 6.01

shows that incubation with H19 RNA produced a marked inhibition of the telomerase activity present in cell extracts from NB4-LR1 cells. The inability of the irrelevant GFP RNA to inhibit telomerase activity demonstrated this selectivity. The inhibitory effect of H19 on telomerase activity is also observed when incubation was performed using NB4-LR1 ${ }^{\mathrm{SFD}}$ cell lysates. Taken together, these data indicate that H19 transcribed in vivo or in vitro could inhibit telomerase activity.

\section{H19 promotes telomerase inhibition by affecting the assembled telomerase complex}

Human telomerase is an RNA binding protein that consists at least of two core subunits, hTERT protein and a template RNA subunit $(h T R)$. Both hTERT and $h T R$ are essential for the assembly of a functional active telomerase in vitro and in vivo [12]. Therefore, we hypothesized that one possible mechanism by which $H 19$ can inhibit telomerase activity might be through its influence on the proper telomerase assembly into a functional complex and might involve $h T R$. To explore this assumption, we performed RNA immunoprecipitations (RIP) on lysates from NB4-LR1 or NB4-LR1 ${ }^{\mathrm{SFD}}$ cells treated or not with ATRA $(1 \mu \mathrm{M})$ for $48 \mathrm{~h}$ with an anti-hTERT antibody or a normal rabbit IgG, and measured by qRT-PCR the amount of hTR in the pellet fraction of the immunoprecipitation reactions. The antibody against hTERT has already been previously validated [13] and was further verified (Additional file 4: Figure S2). Only the $h T R$ bound to hTERT can be recovered in the immune complex. Figure $6 \mathrm{c}$ shows that $h T R$ level was lower in the immunoprecipitates from NB4-LR1 cells treated with ATRA relative to non-treated NB4-LR1 cells. To further investigate a direct role of $\mathrm{H} 19$ on telomerase activity a 


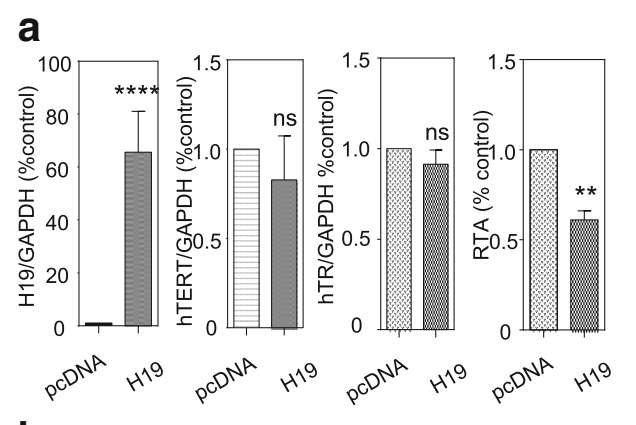

b

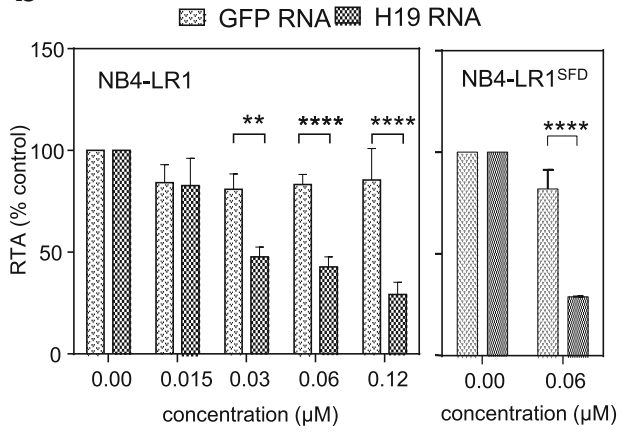

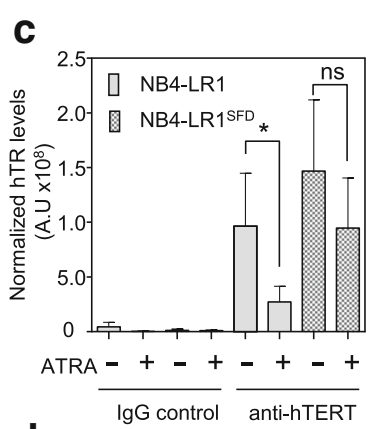

d

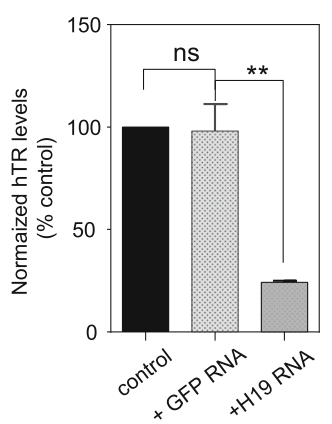

Fig. 6 H19 RNA inhibits telomerase activity by altering the assembled telomerase complex. a Influence of H19 overexpression on hTR and hTERT expression and telomerase activity. NB4 cells were submitted to nucleofection in the presence of H19 (H19-pcDNA) or empty vector (pcDNA). Six hours after nucleofection, proteins and RNA were extracted. The levels of H19, hTR RNA, and hTERT mRNA were quantified by qRT-PCR and normalized to the levels of GAPDH mRNA. RTA was measured by qTRAP. $\mathbf{b}$ In vitro concentration-dependent inhibition of telomerase activity by H19. NB4-LR1 cells were extracted with CHAPS buffer. In vitro transcribed $\mathrm{H} 19$ was incubated with protein extracts for 90 min. Before assessment of telomerase activity. In vitro transcribed GFP was included as a specificity control. RTA measured by qTRAP is expressed as the percentage of that detected in protein extracts not supplemented with RNA molecules. $\mathbf{c}$ Lysates prepared from NB4-LR1 and NB4-LR1 ${ }^{\text {SFD }}$ cells treated or not with ATRA (1 $\left.\mu \mathrm{M}\right)$ for $48 \mathrm{~h}$ were subjected to immunoprecipitation (IP) with IgG or anti-hTERT antibodies. The immunoprecipitates were extracted for $h T R$ analysis by quantitative RT-PCR. $\mathbf{d}$ Lysates from non-treated NB4-LR1 cells were preincubated with in vitro transcribed H19 RNA molecules subjected to IP using the hTERT antibody. The immunoprecipitates were then incubated for $90 \mathrm{~min}$. Co-precipitated RNA were extracted and $h T R$ assembled with hTERT quantified by qRT-PCR. As a control, an in vitro transcribed GFP RNA was used. Results were expressed as means +/- SEM. t-test or two way ANOVA * $p<0.05$, ${ }^{* *} p<0.01,{ }^{* * *} p<0.001,{ }^{* * * *} p<0.0001$

complementary experiment was performed using lysates from NB4-LR1 cells supplemented with either the H19 RNA or an irrelevant GFP RNA, and then subjected to immunoprecipitation. Figure $6 \mathrm{~d}$ shows that the lysate supplementation with $H 19$ decreased the amount of $h T R$ immunoprecipitated with hTERT. As a control for specificity, we added the irrelevant GFP RNA in cell lysate and showed no significant changes in the amount of $h T R$ in the hTERT immunoprecipitate.

\section{Discussion}

In this study, using a pair of well-established cell lines that respond differently to ATRA treatment in terms of telomerase expression, we identified a new pathway through which ATRA can regulate telomerase activity. This new pathway involves $H 19$, a long non-coding RNA.

We have previously shown that in the maturation resistant NB4-LR1 APL cells, ATRA induced a strong transcriptional repression of $h T E R T$ gene expression in the absence of cell differentiation. In the present study, we demonstrated that in parallel, ATRA induces a marked increase of $\mathrm{H} 19$ expression. In contrast, in the NB4-LR $1^{\text {SFD }}$ cell line, which in addition is resistant to ATRA-induced repression of $h T E R T$, ATRA treatment induced a repression of H19. Importantly, treatments of these cells with ATRA combined to either cAMP analogs (to activate PKA signaling pathway and induce differentiation) or arsenic trioxide induced H19. In both cases of treatments, the increase of $H 19$ levels occurs in parallel with the repression of $h T E R T$ suggesting an inverse relationship between H19 and hTERT expression at the level of the RNA. The precise events downstream of ATRA that result in $\mathrm{H} 19$ induction are not known and requires further investigation. An induction of $H 19$ transcription by ATRA has already been described in cells derived from human testicular germ tumors associated with growth inhibition [14]. Notably, exploring the AML patient cohort from TCGA atlas, we found the same 
inverse relationship in the subgroup of APL patient. Even though this subgroup included only 16 patients, taken together these data strongly suggest an inverse relationship between the expression of $h T E R T$ and $H 19$.

Long non-coding RNAs (LncRNAs) have recently emerged as a novel group of non-coding RNAs able to regulate mammalian gene expression. Besides their participation in normal physiology, LncRNA have been implicated in cancer development and progression $[15,16]$.

$H 19$, an oncofetal gene that does not code for a protein, is transcribed to a non-coding RNA. It is located on human chromosome $11 \mathrm{p} 15.5$ within the highly conserved imprinted H19/insulin-like growth factor 2 (IGF2) locus. These two genes are reciprocally imprinted, leading to differential allelic expression of $H 19$ from the maternal allele and IGF2 from the paternal allele [17]. Although $\mathrm{H} 19$ has been intensively studied in genomic imprinting, the function of $\mathrm{H} 19$ as a noncoding RNA has only recently begun to be investigated [18]. H19 was initially identified as a tumor suppressor. Indeed, its overexpression in some tumor cells was associated with inhibition of proliferation, morphological changes, decrease of clonogenicity in soft agar, and tumorigenicity in nude mice [19]. Furthermore, downregulation of $H 19$ gene expression was recognized as an early event in the formation of several tumor types [2022]. However, increased expression of $H 19$ has also been observed in a variety of tumors, suggesting that $H 19$ is, in contrast, essential for tumor growth [23-29]. A link has been well established between $H 19$ and several tumorigenesis related genes, such as c-Myc and E2F1 $[30,31]$. Thus, it remains controversial as to whether $H 19$ functions as a tumor promoter or a tumor suppressor. It is possible that $H 19$ plays differential roles depending on the developmental stage and/or the tissue type. The investigations on $\mathrm{H} 19$ functions were more widely depicted in solid tumors than in leukemia. In addition, the exact mechanism by which $H 19$ as a noncoding RNA functions remain to be elucidated. Long non-coding RNA, including $\mathrm{H} 19$ can directly modulate the transcription of its target genes either by recruitment of chromatin modifiers or sequestration of regulatory proteins or regulate mRNA degradation and translation [32-36]. We have previously shown that epigenetic modifications targeting the distal region of hTERT promoter could account for the capacity of retinoids to repress hTERT [37]. However, investigations using invalidation and overexpression experiments failed to reveal any direct effect of H19 on hTERT expression, which made it unlikely that $H 19$ could have a direct effect on hTERT expression independently of ATRA treatment.

H19 as a primary miRNA transcript generates two mature miRNAs, miR-675-3p and miR-675-5p [9]. These two conserved miRNAs play important roles in the regulation of H19-mediated processes. H19 could, therefore, at least in part, function through these miRNAs. Using bioinformatics miRNA target prediction software indicated $h T E R T$ mRNA as a potential, although poorly conserved, target of miR-675-5p. However, no significant change of the expression of miR-675-5p was observed during ATRA treatment of NB4-LR1 cells, which makes it unlikely a direct action of this miRNA on $h T E R T$ mRNA level.

Many LncRNA, including H19, participate in molecular regulation pathways through their interactions with proteins and modulation of their activities [38]. Telomerase enzyme is unusual: it has a protein component that has an affinity for $h T R$, its natural RNA partner essential for its activity. Using an in vitro telomerase assay, we observed that the addition of in vitro transcribed H19 RNA molecules to protein extracts prepared from either NB4-LR1 or NB4-LR1 ${ }^{\mathrm{SFD}}$ cells inhibited telomerase activity. Furthermore, we demonstrated that the ectopic expression of H19 in NB4 cells induced a decrease of telomerase activity without any modifications of $h T E R T$ expression indicating that the mechanism of action might involve $h T R$. This hypothesis was further supported by the observation that 8 -CPT-cAMP treatment can induce alone an important increase of H19 associated with a notable loss of telomerase activity whereas hTERT expression remained relatively high. Using RIP experiments, we showed that $H 19$ decreases the amount of $h T R$ associated with hTERT component and thereby impairs the functions of this enzyme. We were not able to demonstrate a direct interaction of $H 19$ with either hTERT protein or its RNA component $h T R$. Indeed, the amount of hTERT in a cell is very low [39] and western blot are not sensitive enough to detect the endogenous protein. It is likely that $\mathrm{H19}$ does not bind tightly the telomerase ribonucleoprotein but instead is recruited either transitorily or through another telomerase auxiliary factor. The interaction of hTERT with another RNA component different from $h T R$ has already been reported. Indeed, using a tandem affinity peptide-tagged hTERT protein in Hela S3 cells, Maida et al. identified a heterogeneous mixture of 38 RNA sequences associated with hTERT, including the RNA component of mitochondrial RNA processing endoribonuclease (RMRP) [40]. TERT has also been reported to interact with mitochondrial tRNAs and amino-acylo tRNA synthases [41]. Another possible mechanism for the decrease of $h T R$ binding to hTERT protein is the $H 19$ interference with free $h T R$ preventing it from associating with hTERT.

Our results contrast with those previously published [42] showing that overexpression of H19 enhances the binding of hTERT to $h T R$ and leads to an increase of telomerase activity. In this study, $\mathrm{Pu}$ et al. provided no information regarding the hTERT antibody used in the RIP 


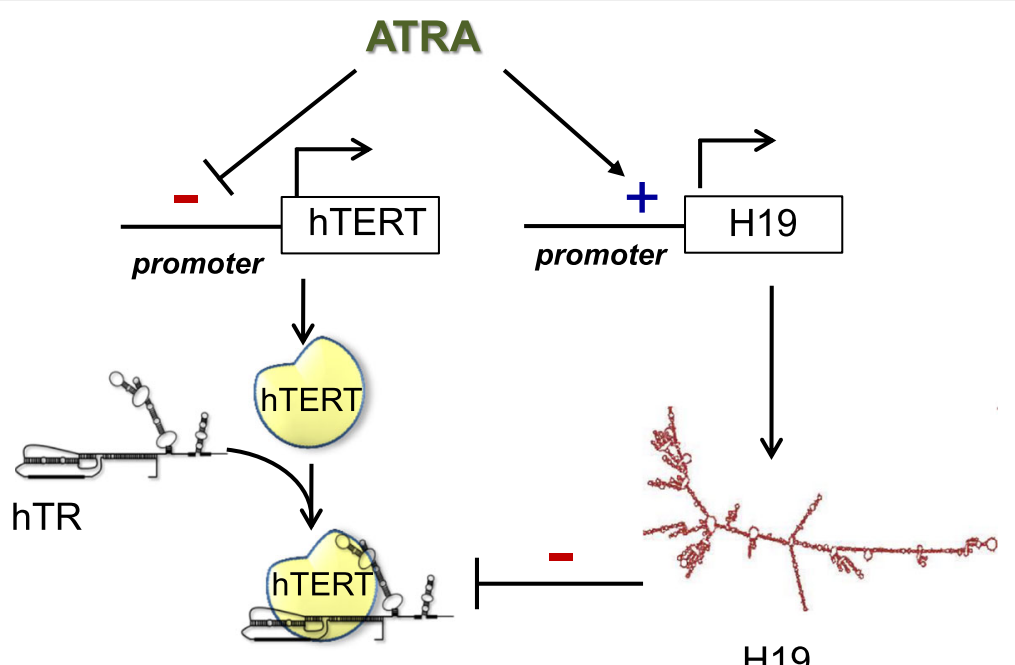

Fig. 7 Hypothetic schematic overview of the relationship between H19 and hTERT in ATRA treated APL cells. ATRA might target telomerase through two distinct processes to ensure a sustained inhibition of telomerase activity, first by decreasing $h T E R T$ gene transcription and consequently the amount of hTERT protein, and second, by increasing H19 level, which in turn may impede telomerase assembly and functions

experiment performed. However, the lack of specificity of most commercially available antibodies directed against the hTERT protein is well-known within the scientific community in this field [13]. The specificity of the antibody used here has already been well characterized [13] and further verified in the present work. Another explanation for such discrepancy is the difference in the cellular model used in their study (liver cancer stem cells). One possibility is that, $H 19$ could be a molecular chaperone able to promote either the association or the dissociation of hTERT to $h T R$, depending on the cellular context.

Our results have broader implications considering the antitelomerase action of retinoids and thereby their antitumor properties independently of their effects on differentiation: we propose that ATRA might target telomerase through two distinct processes to ensure a sustained inhibition of telomerase activity, first by decreasing hTERT gene transcription and consequently the amount of hTERT protein, and second, by increasing H19 level, which in turn may impede telomerase assembly and functions (Fig. 7). Further studies are required to fully elucidate the precise mechanisms by which H19 interfere with the activity of the telomerase complex.

\section{Conclusions}

In conclusion, this study identifies for the first time a new level of telomerase regulation through the involvement of $H 19$, and thereby reveals also a novel function for this LncRNA in telomerase biology. It also suggests that directly targeting hTERT/hTR complex through an increase of $H 19$ might provide a new treatment strategy for cancer that could have clinical utility.

\section{Additional files}

Additional file 1: Table S1. Primer sequences. (DOCX $21 \mathrm{~kb}$ )

Additional file 2: Table S2. Data analysis of the microarray experiments. Lists of genes with significant differential expression levels (fold changes of \pm 2 fold; $p<0.01$ ). Some details correspond to the results displayed in Venn diagrams presented in Fig. 1c of the main text. (XLSX $66 \mathrm{~kb}$ )

Additional file 3: Figure S1. Expression levels of mir-675-5p and mir-675-3p in non-treated (a) and after $1 \mu \mathrm{M}$ ATRA treatment (b) of NB4-LR1 and NB4-LR1 ${ }^{\text {SFD }}$ cells. Expression levels were normalized to SNORD44 expression. Results were expressed as means $+/-$ SEM. One way ANOVA with post-hoc Tukey, ns $p>0.05,{ }^{*} p<0.05,{ }^{* * *} p<0.001$. (PDF $103 \mathrm{~kb}$ )

Additional file 4: Figure S2. Validation of the anti-hTERT antibody specificity. Immunoprecipitation of the hTERT/hTR complex was performed using an anti-hTERT antibody (Rockland) or pre-immune lgG as described in Material and Methods. The presence of $h T R$ was detected by quantitative RT-PCR. Results were expressed as means $+/-$ SEM. t-test ${ }^{*} p<0.05$. (PDF $90 \mathrm{~kb})$
Abbreviations
APL: Acute promyelocytic leukemia; ATRA: All-trans retinoic acid; GAPDH: Glyceraldehyde-3-phosphate dehydrogenase; GFP: Green fluorescent protein; hTERT: Human telomerase reverse transcriptase; hTR: Human telomerase RNA; IP: Immunoprecipitation; LncRNA: Long non-coding RNA; qRT-PCR: Quantitative reverse transcriptase polymerase chain reaction; qTRAP: Quantitative telomeric repeats amplification protocol

\section{Acknowledgements}

We thank Yann Blondin for technical support in the detection of miR-675-3p and miR-675-5p by quantitative RT-PCR.

\section{Funding}

The work of the authors was supported by grants from the French National Institute of Health and Medical Research (INSERM), the National Center for Scientific Research (CNRS), the Fondation de France ( $n^{\circ}$ 201300038226), the French National Research Agency (ANR), Gefluc, Agence Universitaire de la Francophonie (AUF), Hubert Curien Partnership (PHC-CEDRE). 


\section{Availability of data and materials}

The dataset supporting the conclusions of this article is included within the article and its additional file. H19 and hTERT expression data of APL patients of TCGA was extracted from expression dataset from Cancer Bioportal (http://www.cbioportal.org/).

\section{Authors' contributions}

$J E H, C B, E N$, QYL performed the experimental work. JEH, EN, and ESB analyzed the data. EA contributed biological materials. JEH, CB, EN, EA, and GH contributed for the drafted manuscript and for its critical revision. E.SB. design the study and wrote the manuscript. Final manuscript was read and approved by all authors. All authors discussed the results and commented on the manuscript.

\section{Ethics approval and consent to participate}

Not applicable.

\section{Competing interests}

The authors declare that they have no competing interests.

\section{Publisher's Note}

Springer Nature remains neutral with regard to jurisdictional claims in published maps and institutional affiliations.

\section{Author details}

'INSERM UMR-S 1007, Cellular Homeostasis and Cancer, Paris, France. ${ }^{2}$ Paris-Descartes University, Paris Sorbonne Cité, Paris, France. ${ }^{3}$ Paris-Sud University, Paris-Saclay University, Orsay, France. ${ }^{4}$ Cancer and Metabolism Laboratory, Faculty of Medicine, Saint-Joseph University, Beirut, Lebanon. ${ }^{5}$ INSERM U 908, University Lille 1, Villeneuve d'Ascq, France. ${ }^{6}$ Present address: Bristol-Myers Squibb (China) Investment Co. Ltd., Shanghai 200040, People's Republic of China. ${ }^{7}$ INSERM UMR-S 1007, Paris-Descartes University, 45 rue des Saints-Pères, 75006 Paris, France.

\section{Received: 28 December 2017 Accepted: 16 April 2018}

\section{Published online: 27 April 2018}

\section{References}

1. Shay JW, Wright WE. Role of telomeres and telomerase in cancer. Semin Cancer Biol. 2011;21:349-53.

2. Smith $L L$, Coller HA, Roberts JM. Telomerase modulates expression of growth-controlling genes and enhances cell proliferation. Nat Cell Biol. 2003:5:474-9.

3. Jafri MA, Ansari SA, Alqahtani MH, Shay JW. Roles of telomeres and telomerase in cancer, and advances in telomerase-targeted therapies. Genome Med. 2016;8:69.

4. Pendino F, Tarkanyi I, Dudognon C, Hillion J, Lanotte M, Aradi J, Segal-Bendirdjian E. Telomeres and telomerase: pharmacological targets for new anticancer strategies? Curr Cancer Drug Targets. 2006;6:147-80.

5. Pendino F, Flexor M, Delhommeau F, Buet D, Lanotte M, Segal-Bendirdjian E. Retinoids down-regulate telomerase and telomere length in a pathway distinct from leukemia cell differentiation. Proc Natl Acad Sci U S A. 2001;98:6662-7.

6. Pendino F, Dudognon C, Delhommeau F, Sahraoui T, Flexor M, Bennaceur-Griscelli A, Lanotte M, Segal-Bendirdjian E. Retinoic acid receptor alpha and retinoid-X receptor-specific agonists synergistically target telomerase expression and induce tumor cell death. Oncogene. 2003:22:9142-50.

7. Pendino F, Sahraoui T, Lanotte M, Segal-Bendirdjian E. A novel mechanism of retinoic acid resistance in acute promyelocytic leukemia cells through a defective pathway in telomerase regulation. Leukemia. 2002;16:826-32.

8. Wege H, Chui MS, Le HT, Tran JM, Zern MA. SYBR green real-time telomeric repeat amplification protocol for the rapid quantification of telomerase activity. Nucleic Acids Res. 2003;31:E3.

9. Cai $X$, Cullen BR. The imprinted H19 noncoding RNA is a primary microRNA precursor. RNA. 2007;13:313-6.

10. Ruchaud S, Duprez E, Gendron MC, Houge G, Genieser HG, Jastorff B, Doskeland SO, Lanotte M. Two distinctly regulated events, priming and triggering, during retinoid-induced maturation and resistance of NB4 promyelocytic leukemia cell line. Proc Natl Acad Sci U S A. 1994;91:8428-32.
11. Tarkanyi I, Dudognon C, Hillion J, Pendino F, Lanotte M, Aradi J, Segal-Bendirdjian E. Retinoid/arsenic combination therapy of promyelocytic leukemia: induction of telomerase-dependent cell death. Leukemia. 2005;19:1806-11.

12. Blackburn EH. Telomerases. Annu Rev Biochem. 1992;61:113-29.

13. Wu YL, Dudognon C, Nguyen E, Hillion J, Pendino F, Tarkanyi I, Aradi J, Lanotte M, Tong JH, Chen GQ, Segal-Bendirdjian E. Immunodetection of human telomerase reverse-transcriptase (hTERT) re-appraised: nucleolin and telomerase cross paths. J Cell Sci. 2006;119:2797-806.

14. Kopf E, Bibi O, Ayesh S, Tykocinski M, Vitner K, Looijenga LH, de Groot N, Hochberg A. The effect of retinoic acid on the activation of the human $\mathrm{H} 19$ promoter by a 3' downstream region. FEBS Lett. 1998;432:123-7.

15. Wang KC, Chang HY. Molecular mechanisms of long noncoding RNAs. Mol Cell. 2011;43:904-14.

16. Tsai MC, Spitale RC, Chang HY. Long intergenic noncoding RNAs: new links in cancer progression. Cancer Res. 2011;71:3-7.

17. Gabory A, Jammes H, Dandolo L. The H19 locus: role of an imprinted non-coding RNA in growth and development. BioEssays. 2010;32:473-80.

18. Raveh E, Matouk IJ, Gilon M, Hochberg A. The H19 long non-coding RNA in cancer initiation, progression and metastasis - a proposed unifying theory. Mol Cancer. 2015;14:184

19. Hao Y, Crenshaw T, Moulton T, Newcomb E, Tycko B. Tumour-suppressor activity of H19 RNA. Nature. 1993:365:764-7.

20. Steenman MJ, Rainier S, Dobry CJ, Grundy P, Horon IL, Feinberg AP. Loss of imprinting of IGF2 is linked to reduced expression and abnormal methylation of H19 in Wilms' tumour. Nat Genet. 1994;7:433-9.

21. Cui H, Hedborg F, He L, Nordenskjold A, Sandstedt B, Pfeifer-Ohlsson S, Ohlsson R. Inactivation of H19, an imprinted and putative tumor repressor gene, is a preneoplastic event during Wilms' tumorigenesis. Cancer Res. 1997:57:4469-73.

22. Yoshimizu T, Miroglio A, Ripoche MA, Gabory A, Vernucci M, Riccio A, Colnot S, Godard C, Terris B, Jammes H, Dandolo L. The H19 locus acts in vivo as a tumor suppressor. Proc Natl Acad Sci U S A. 2008;105:12417-22.

23. Collette J, Le Bourhis $X$, Adriaenssens E. Regulation of human breast Cancer by the long non-coding RNA H19. Int J Mol Sci. 2017;18(11):2319. https:// doi.org/10.3390/ijms18112319.

24. Ariel I, Lustig O, Schneider T, Pizov G, Sappir M, De-Groot N, Hochberg A. The imprinted $\mathrm{H} 19$ gene as a tumor marker in bladder carcinoma. Urology. 1995:45:335-8

25. Tanos V, Prus D, Ayesh S, Weinstein D, Tykocinski ML, De-Groot N, Hochberg A, Ariel I. Expression of the imprinted H19 oncofetal RNA in epithelial ovarian cancer. Eur J Obstet Gynecol Reprod Biol. 1999;85:7-11.

26. Hibi K, Nakamura H, Hirai A, Fujikake Y, Kasai Y, Akiyama S, Ito K, Takagi H. Loss of H19 imprinting in esophageal cancer. Cancer Res. 1996:56:480-2.

27. Kondo M, Suzuki H, Ueda R, Osada H, Takagi K, Takahashi T, Takahashi T. Frequent loss of imprinting of the $\mathrm{H} 19$ gene is often associated with its overexpression in human lung cancers. Oncogene. 1995;10:1193-8.

28. Lottin S, Adriaenssens E, Dupressoir T, Berteaux N, Montpellier C, Coll J, Dugimont T, Curgy JJ. Overexpression of an ectopic $\mathrm{H} 19$ gene enhances the tumorigenic properties of breast cancer cells. Carcinogenesis. 2002;23:1885-95.

29. Tanos V, Ariel I, Prus D, De-Groot N, Hochberg A. H19 and IGF2 gene expression in human normal, hyperplastic, and malignant endometrium. Int J Gynecol Cancer. 2004:14:521-5.

30. Barsyte-Lovejoy D, Lau SK, Boutros PC, Khosravi F, Jurisica I, Andrulis IL, Tsao MS, Penn LZ. The c-Myc oncogene directly induces the $\mathrm{H} 19$ noncoding RNA by allele-specific binding to potentiate tumorigenesis. Cancer Res. 2006;66:5330-7.

31. Berteaux N, Lottin S, Monte D, Pinte S, Quatannens B, Coll J, Hondermarck H, Curgy JJ, Dugimont T, Adriaenssens E. H19 mRNA-like noncoding RNA promotes breast cancer cell proliferation through positive control by E2F1. J Biol Chem. 2005;280:29625-36.

32. Monnier P, Martinet C, Pontis J, Stancheva I, Ait-Si-Ali S, Dandolo L. H19 IncRNA controls gene expression of the imprinted gene network by recruiting MBD1. Proc Natl Acad Sci U S A. 2013:110:20693-8.

33. Shi X, Sun M, Liu H, Yao Y, Song Y. Long non-coding RNAs: a new frontie in the study of human diseases. Cancer Lett. 2013;339:159-66.

34. Sun $W$, Yang $Y, X u C$, Guo J. Regulatory mechanisms of long noncoding RNAs on gene expression in cancers. Cancer Genet. 2017:216-217:105-10.

35. Giovarelli M, Bucci G, Ramos A, Bordo D, Wilusz CJ, Chen CY, Puppo M, Briata P. Gherzi R. H19 long noncoding RNA controls the mRNA decay promoting function of KSRP. Proc Natl Acad Sci U S A. 2014;111:E5023-8. 
36. Bi HS, Yang XY, Yuan JH, Yang F, Xu D, Guo YJ, Zhang L, Zhou CC, Wang F, Sun SH. H19 inhibits RNA polymerase II-mediated transcription by disrupting the hnRNP U-actin complex. Biochim Biophys Acta. 1830;2013:4899-906.

37. Azouz A, Wu YL, Hillion J, Tarkanyi I, Karniguian A, Aradi J, Lanotte M, Chen GQ, Chehna M, Segal-Bendirdjian E. Epigenetic plasticity of hTERT gene promoter determines retinoid capacity to repress telomerase in maturation-resistant acute promyelocytic leukemia cells. Leukemia. 2010;24:613-22.

38. Marchese FP, Raimondi I, Huarte M. The multidimensional mechanisms of long noncoding RNA function. Genome Biol. 2017;18:206.

39. Xi L, Cech TR. Inventory of telomerase components in human cells reveals multiple subpopulations of hTR and hTERT. Nucleic Acids Res. 2014:42:8565-77.

40. Maida Y, Yasukawa M, Furuuchi M, Lassmann T, Possemato R, Okamato N, Kasim V, Hayashizaki Y, Hahn WC, Masutomi K. An RNA-dependent RNA polymerase formed by TERT and the RMRP RNA. Nature. 2009;461:230-5.

41. Sharma NK, Reyes A, Green P, Caron MJ, Bonini MG, Gordon DM, Holt IJ, Santos JH. Human telomerase acts as a hTR-independent reverse transcriptase in mitochondria. Nucleic Acids Res. 2012:40:712-25.

42. Pu H, Zheng Q, Li H, Wu M, An J, Gui X, Li T, Lu D. CUDR promotes liver cancer stem cell growth through upregulating TERT and C-Myc. Oncotarget. 2015:6:40775-98.

Ready to submit your research? Choose BMC and benefit from:

- fast, convenient online submission

- thorough peer review by experienced researchers in your field

- rapid publication on acceptance

- support for research data, including large and complex data types

- gold Open Access which fosters wider collaboration and increased citations

- maximum visibility for your research: over $100 \mathrm{M}$ website views per year

At BMC, research is always in progress.

Learn more biomedcentral.com/submissions 